\title{
LOVE \\ FOR GRUNDTVIG-SELSKABET
}

\section{AF 8. SEPTEMBER 1947}

$\S$ I. Selskabets formål er at fremme studiet af N.F.S. Grundtvig, hans virke og hans stilling $\mathrm{i}$ åndslivet $\mathrm{i}$ og udenfor Danmark.

$\S$ 2. Selskabet udgiver årbogen Grundtvig-Studier, der vederlagsfrit tilstilles medlemmerne, og kan tillige udgive andre studier eller tekster vedrørende N.F.S. Grundtvig, hvilke tilbydes medlemmerne til favørpris.

$\S$ 3. Selskabet optager som medlemmer såvel danske som udenlandske enkeltpersoner og institutioner.

$\S$ 4. På Selskabets årsmøde, hvortil medlemmerne indkaldes med mindst 2 ugers varsel, aflægges beretning og regnskab og foretages valg.

$\S$ 5. a. Selskabets styrelse består af indtil 25 medlemmer, valgt for 5 år, idet indtil 5 medlemmer afgår hvert år. Genvalg kan finde sted.

$\S 5$. b. Hvis en styrelsesplads bliver ledig mellem to årsmøder, kan styrelsen supplere sig med et nyt medlem indtil næste årsmøde.

$\S 6$. Styrelsen vælger af sin midte formand, næstformand, sekretær og redaktør af Grundtvig-Studier samt kasserer. Denne kan vælges udenfor styrelsen. Disse udgør forretningsudvalget, og valgene gælder for tre år.

Genvalg kan finde sted.

$\S$ 7. Styrelsen holder møde i tilslutning til årsmødet. Udenfor dette tidspunkt kan formanden indkalde til ekstraordinært styrelsesmøde med mindst I4 dages varsel.

$\S$ 8. Såvel årsmødet, som styrelsen eller forretningsudvalget kan nedsætte udvalg til varetagelsen af særlige opgaver.

$\S$ 9. Kontingentet fastsættes på årsmødet og udgør for tiden ıo kr., for studerende $6 \mathrm{kr}$.

$\S$ Io. Regnskabet, der følger kalenderåret, gennemgås af 2 revisorer valgt af årsmødet for 3 år.

Genvalg kan finde sted.

$\S$ I I. Lovændringer vedtages af årsmødet og forslag derom tilstilles formanden senest 15 . august før årsmødet.

Således vedtaget på årsmødet 9. september 1957. 